\title{
Application of a Shunting Method in Self-Government for the Synthesis of Homeostatic Regulators
}

\author{
Zernov S.V. \\ Institute of Control of Sciences of the RAS, \\ Moscow, Russia, \\ 5219528@mail.ru
}

\begin{abstract}
The article examines the relationship of two independent systems with shared limited but renewable resources. Their antagonistic struggle leads to the dispersal of resources and even to the mutual destruction of systems. Therefore, the mutual development of the two systems due to homeostatic control seems to be the best solution. But human history shows that homeostatic control cannot be achieved or it will be a temporary compromise as long as there is an antagonistic contradiction. Therefore, it is proposed to consider an alternative way - the creation of new social mechanisms in parallel with the existing ones. In practice, in various areas, the restoration of temporarily lost function is carried out by using the shunting method. This can contribute to the creation of a social institution of social construction to start the process of social Telesis, without waiting for the moment when social Genesis will lead humanity to collapse.
\end{abstract}

Keywords-homeostatic control, shunting method, bureaucracy, social parasite, self-government, social institute

\section{INTRODUCTION}

A hundred years before $\mathrm{H}$. Wiener formulated the foundations of alternative cybernetics - the science of managing human collectives, which was not realized and was forgotten, wrote Y.M. Gorsky, referring to N.N. Moiseev. In his opinion, cybernetics in the foreseeable future would have been a theory of control of large systems containing active elements and subsystems (people and entire groups). However, in modern cybernetics, the role of contradiction is not studied at all. Whereas in Marxist philosophy and before the cybernetics of $\mathrm{H}$. Wiener, the contradiction was in the center of attention. Therefore, we must consider management problems from the standpoint of dialectics. For purposes of illustration, Yu.M. Gorsky presents a qualitative electrical model that shows the relationship between systems $\mathrm{A}$ and $\mathrm{B}$ with a limited but renewable resource [1]. The study of the interaction of systems in Fig. 1 leads to three critical cases: the capture of resources by system A and the death of system B, the consistent intensive nature of the development of systems, a simultaneous attempt to capture the resource by systems A and B at their parity. Mutual development of systems A and B through homeostatic control is the best solution. However, human history shows that homeostatic control cannot be achieved or it will be a temporary compromise as long as there is no antagonistic contradiction (social parasite - social creator). Therefore, the control system, governed by social parasitism, constantly strives to gain an advantage over a healthy system. For this, any possible advantages or provided opportunities are used, and human and material losses are ignored [2]

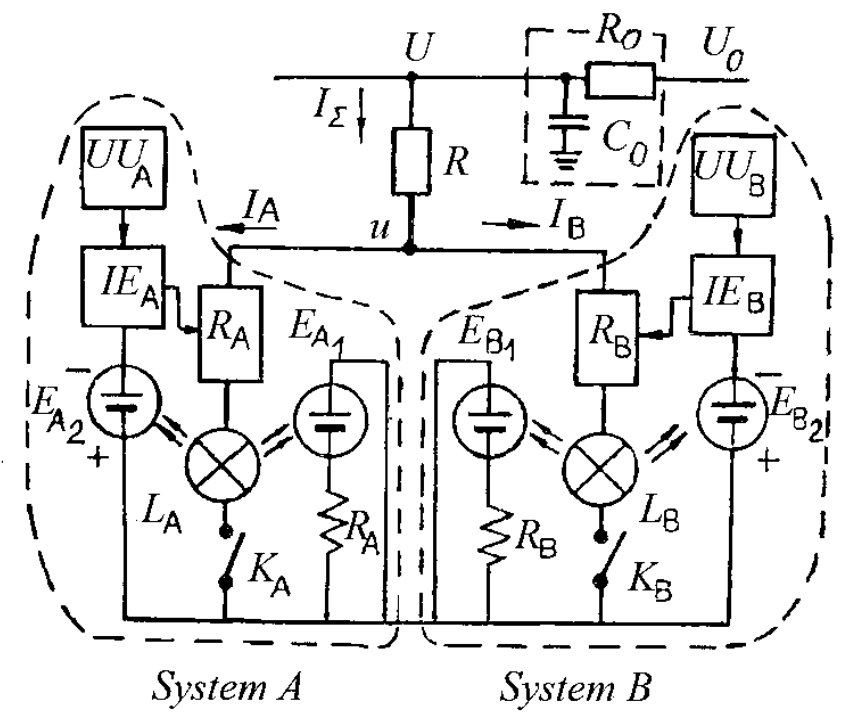

Fig. 1. Electric circuit of system interaction 
Since social parasites never sacrifice themselves and are ready to abandon any elements of the system in order to impose their way of life and will on another system. If not enslave, then subjugate. Such interaction can be observed almost every time, except for those rare cases when the leadership of the aggressor is cowardly or weak.

\section{THE Synthesis OF HomeOSTATIC Regulator PROBLEM}

In the absence of the intervention of God as arbiter and Cerberus, the interaction of these systems will be clearly expressed as a constant struggle due to the lack of the ability to achieve dynamic equilibrium. Each of the parties involved in this struggle see the best solution as a victory over the enemy, his moral and physical defeat. If we consider that such a system consists of states, then the citizens of these states become hostages of such a struggle. A striking example of such an antagonistic contradiction is The Second World War. During this war, tens of millions of citizens of both sides were killed, who were forced to attack or defend because they were involved in an antagonistic conflict between the leaders of these countries. Fascist Germany wanted to impose its will and enslave the citizens of the USSR, while the USSR fought the "brown plague" that spread first in Europe and then around the world.

According to Erich Fromm [3], the leadership of fascist Germany was smitten with necrophilic intentions, and the leadership of the USSR defended the right to a biophilic path of development of their country. The leadership of fascist Germany was dictatorial, and the USSR was authoritarian. This behavior of leaders will continue in the future, as no one has proposed a solution to the problem.

\section{CONTROLLED SOCIAL EVOLUTION}

In connection with the above and the impossibility of constructing and coordinating a homeostatic regulator between systems $\mathrm{A}$ and $\mathrm{B}$, it is proposed to consider a fundamentally different way of resolving this antagonistic contradiction. It is based on the hypothesis that social parasitism affects systems in which there has been stagnation and decline in development, violation of social self-regulation, etc. In other words, such systems are sick (unhealthy), and it is not difficult for social parasites to understand the control system in them. The task of the elements of both systems (citizens) is to obtain a level of social control at which self-government can be maintained. This can be achieved by creating systems of self-government at various levels in parallel with the existing systems of selfgovernment, affected by social parasitism, corruption and bureaucracy. To study the existing ways to solve this problem, it is proposed to consider the key diagram in Fig. 2, which determines the features of the interaction of the parties [4].

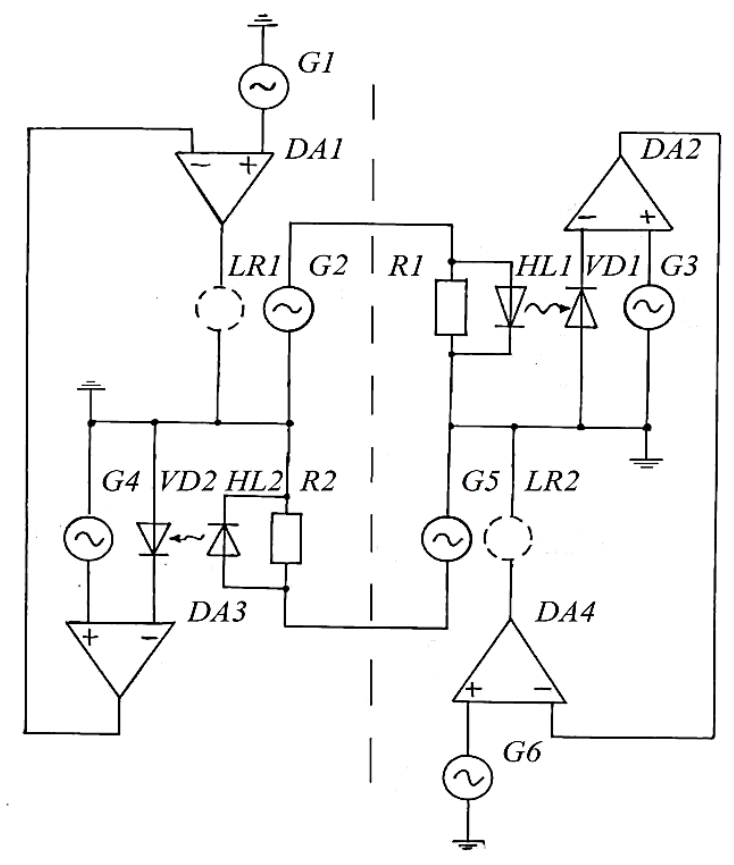

Fig 2. Key diagram of reciprocity

\section{One MAN doES NOT MAKE A TEAM}

If we go to the level of social coordination, it is obvious that citizens themselves are a set of elements that individually accumulate social experience and knowledge, and the level of coordination processes and synchronized actions [5] among them depends on the number of participants and the variety of their ideas, motives, etc. e. The only activity in which they can make acceptable progress is a peaceful controlled mob [6] or guerrilla units. Unlike the aggregate of citizens, the state bureaucracy always acts as an organized community that has control over many resources, knowledge and skills to oppose and prevent the activities of any combination of active citizens who try to operate within the law. In other words, bureaucracy is an organized intellectual system, the main and most important goal of which is to protect and defend its own interests. And an active citizen is an unpleasant problem for making a profit.

In such circumstances, citizens or associations of citizens have no opportunity to force the bureaucratic machine to act in their interests [7]. Moreover, they cannot begin the purposeful process of healing social control organizations - getting rid of social parasites and corrupt officials. [8] The destiny of citizens is to close social gaps under the leadership of various charitable foundations, which can quickly transform from non-profit organizations to commercial enterprises serving the interests of the oligarchy. Mercenaries like Greenpeace are a good example of this.

\section{Using SHUNTING METHOD TO CREATE NEW SOCIAL MECHNISMS}

Therefore, it is proposed to consider an alternative way - a way of creating new social mechanisms in parallel with existing ones. New social mechanisms, including mechanisms of social 
control, are more effective and safe, they are capable of solving the problems facing society [12]. Inappropriate social mechanisms must be replaced with workable ones. The next inevitable step will be to replace the social control system of these useful social mechanisms. In practice, in various areas, the restoration of a temporarily lost function is carried out in a shunting way in the same way: road repair, bone fusion, bypassing faulty signaling zones, etc.

But this is not enough to create a homeostatic regulator, because it is required to integrate a set of created mechanisms into an existing system capable of performing the required functions [13]. To do this, we can use the advances in informatization $[14,15]$, operating the best practices of the architectural approach, creating a repository of service states, etc. harmonious development. This can be achieved if the management company is used as elementary devices of the control system. The company exercises control over the administration through feedback channels, as well as with the help of citizens and public associations that act as founders and beneficiaries of the activities of such systems.

\section{CONCLUSION}

As a result, it is possible to achieve controlled evolution using gradual modernization and change of self-government systems for service-oriented companies. Such service-oriented companies will function in the interests and under the control of socially active citizens to solve the problems of self-government.

At the same time, it is necessary to get rid of the harmful illusion and give up the possibility of spontaneous collective self-organization. Therefore, it is impossible to achieve the participation of every citizen in social control systems that would be more stable and effective than a state organization. Practical experience shows the social fiction of this idea, since it is absolutely speculative. On the contrary, professional communities demonstrate the most effective development [9]. Stability is achieved by collective responsibility for the results of their work (self-regulatory organizations). Therefore, it is also necessary to promote the creation of a social institution of social construction in order to start the process of social Telesis [10], without waiting for the moment when social genesis will lead humanity to collapse.

\section{PERSPECTIVES}

The first step in this direction will be the creation and natural mass distribution of non-profit social control companies that operate on a professional rather than voluntary basis. They will be established by citizens and subject to themselves [11]. They will act solely in their own interests, directly regulated and monitored through feedback. The next step in the evolution of a social institution will be the creation of a public association of non-profit social control companies. Mandatory requirements for joining an association of non-profit social control companies must be voluntary contributions or income from services provided to the citizens who founded the company. The third step in social evolution will be the transfer of the overwhelming majority of the functions of state, regional and local selfgovernment to such organizations. The final stage in the creation of a social institution will be the transition to optimization of functions, sustainable demand and satisfaction of citizens of non-profit social companies.

\section{REFERENCES}

[1] Y.M. Gorskiy, "System information analysis of management processes" ["Sistemno-informatsionnyy analiz protsessov upravleniya"], Novosibirsk, Nauka, 1988. (In Russ.)

[2] L. Hernández, "Crisis civilizatoria, energías limpias y gestión local", Ciencia Política, 2018, pp. 127-145.

[3] E. Fromm, "The anatomy of human destructiveness" ["Anatomiya chelovecheskoj destruktivnosti”], M.: Respublik, 1994. (In Russ.).

[4] S.V. Zernov and F.F. Pashchenko, "Application of social circuitry for the analysis of social control schemes" ["Primeneniye sotsial'noy skhemotekhniki dlya analiza protsessov sotsial'nogo upravleniya"] Modeling in the socio-political sphere [Modelirovaniye $\mathrm{v}$ sotsial'nopoliticheskoy sfere], 2009, vol. 1(3), pp. 4-11. (In Russ.)

[5] B. Garcia, "New citizenship in Spain: from social cooperation to selfgovernment", Citizenship Studies, 2017, pp. 455-467.

[6] T. Groves, N. Townson, I. Ofer and A. Herrera, "The Right to the City and the Right to the State: Neighbourhood Associations and the Negotiation of Citizenship", Social Movements and the Spanish Transition, Palgrave Studies in the History of Social Movements, Palgrave Macmillan, 2017.

[7] V.V. Petukhov, "Civic participation in russia today: Interaction of socia and political practices", Sociological Studies, 2019, vol. 12, pp. 3-14. (In Russ.).

[8] C. Calvet and C.D. Di Nella, "Contrahegemonías antirrepresivas. Un estudio de caso de la protesta en Barcelona (2011-2015)", Política y Sociedad, 2020, vol. 57(1), pp. 143-173.

[9] S.N. Rohmad, E. Sutadji and Yoto, "The Vocational Education Needs in Managing Local Potential in Upland and Coastal Areas: A Perspective of Local Government, International Journal of Innovation", Creativity and Change, Special Edition, ICOVET, 2019, vol. 8(1), pp. 377-386.

[10] L.F. Uord, "Essays on sociology" [“Ocherki sociologii”], Moscow: URSS 2016. (In Russ.).

[11] S. Splichal, "A Marxist Approach to Communication Freedom”, TripleC 2020, vol. 18(1), pp. 337-349.

[12] A. Cervantes, M. Velázquez and J.L. Pimentel, "Goverment and loca administration of drinking water in the Ciénega de Chapala, Michoacan, Mexico", Water Technology and Sciences, 2017, vol. 8(1), pp. 65-80.

[13] N.R. Rauf, "Strategic Development Towards a Self-Sufficiency Village in Indonesia", Espacios, 2018, vol. 39(42), p. 38.

[14] F. Pashchenko and S. Zernov, "e-Government and Service Oriented Architecture", in Proceedings of 4th International Conference on Application of Information and Communication Technologies (AICT2010), 2010, pp.71-74. (In Russ.).

[15] B. Gayan, "Challenges of DLT-enabled Scalable Governance and the Role of Standards", Journal of ICT, River Publishers, 2019, vol. 7(3), pp. 195208 . 